Gut, 1962, 3, 240

\title{
Urinary xylose excretion in steatorrhoea
}

\author{
MARGOT SHINER, B. J. VAKIL, AND PAMELA B. WILCOX \\ From the Department of Gastroenterology, Central Middlesex Hospital, London
}

EDITORIAL SYNOPSIS The urinary xylose excretion is low in patients with untreated idiopathic steatorrhoea but subsequent improvement in excretion was noted after treatment in six out of nine patients. This did not coincide with histological improvement. With Crohn's disease low values were found when the jejunum but not the ileum was involved.

The numerous articles on xylose excretion published in recent years seem to testify to the reliability of this test (Benson, Culver, Ragland, Jones, Drummey, and Bougas, 1957; Turner, 1950; Brien, Turner, Watson, and Geddes, 1952) and its diagnostic value in certain types of steatorrhoea, and it is generally agreed that as an index of carbohydrate absorption the xylose excretion test is superior to the glucose tolerance test (Butterworth, Perez-Santiago, Martinez de Jesus, and Santini, 1959; Christiansen, Kirsner, and Ablaza, 1959; Finlay and Wightman, 1958). We have therefore studied the xylose excretion in a group of 49 subjects in whom other clinical and biochemical tests were carried out at the same time and who were also subjected, in the majority of cases, to peroral small intestinal biopsy (Shiner, 1956). These subjects consist of controls as well as patients without steatorrhoea, and patients with idiopathic steatorrhoea, regional enteritis, and post-gastrectomy steatorrhoea. We are also presenting our observations on repeat xylose, faecal fat, and biopsy tests in some of the patients with idiopathic steatorrhoea, performed a variable time after starting them on a gluten-free diet.

\section{METHOD AND MATERIAL}

The xylose excretion test was carried out in the following way. The patient was fasted for at least eight hours before the test. The bladder was completely emptied and the urine saved. An oral dose of $25 \mathrm{~g}$. $\mathrm{D}(+)$ xylose dissolved in $500 \mathrm{ml}$. of water was then given. All urine passed during and at the end of the next five hours was collected and pooled. The xylose content of the fivehour and the fasting urine was measured by the colorimetric method of Roe and Rice (1948) which is specific for pentose determinations. Faecal fat estimations (Anderson, French, Sammons, Frazer, Gerrard, and Smellie, 1952) were the average of a three-day collection in all except one patient.
The 49 subjects studied consisted of 17 controls and of 16 patients with idiopathic steatorrhoea, 11 with regional enteritis, and five with post-gastrectomy steatorrhoea (Table I). The average age of the 17 control subjects was 44.4 years, 10 being below the age of 50 (average age 33.9 years) and seven above (average age 59.4 years). Seven of the 17 subjects were chosen from amongst our staff and no further tests were carried out. A further six presented with anaemia (two patients) and diarrhoea of unknown cause (four patients). In all of these faecal fat estimations were found to be within normal limits (below $5 \mathrm{~g}$. in 24 hours) and in the five patients subjected to peroral biopsy the mucosal appearances of the jejunum were normal. Since most of the control subjects were under the age of 50 a further four patients above the age of 50 suffering from haematemesis (two patients), minor abdominal pain of unknown origin (one patient), and cholelithiasis (one patient) were included in this group.

The 16 patients with idiopathic steatorrhoea had an average age of 54.8 years. All were subjected to faecal fat determinations, small bowel radiographs, and mucosal biopsies as part of a diagnostic confirmation. No treatment had been given before their investigation. Repeat xylose excretion tests and faecal fat estimations were carried out in nine of the 16 patients after treatment with a gluten-free diet. At the same time six of the nine patients were subjected to repeat peroral biopsies.

Of the patients with active regional enteritis (average age 40.5 years), four had involvement of the jejunum and seven of the ileum. This was determined either by radiology of the small intestine or at laparotomy (Table I). Three of the four patients with jejunal involvement were found to have steatorrhoea but only one of the seven patients with ileal disease excreted more fat than normal. Jejunal mucosal biopsies were obtained in three of four patients and were normal in two and abnormal in one with jejunal disease. Of the seven patients with ileal disease, mucosal biopsies were obtained in five and were found to be normal in four and only slightly abnormal in one of these.

In the five patients presenting with post-gastrectomy diarrhoea, a Polya partial gastrectomy had been performed in four and a total gastrectomy in the fifth patient. 
TABLE I

PATIENTS STUDIED IN PRESENT SERIES

\begin{tabular}{|c|c|c|c|c|c|c|}
\hline Group & Sex & Age & $\begin{array}{l}\text { Urinary } \\
D(+) \text { Xylose } \\
\text { Excretion } \\
\text { (g./5 hours) }\end{array}$ & $\begin{array}{l}\text { Faecal Fats } \\
(\mathrm{g} . / 24 \mathrm{hr} .)\end{array}$ & $\begin{array}{l}\text { Result of Barium } \\
\text { Meal and Follow } \\
\text { Through }\end{array}$ & Small Intestinal Biopsy \\
\hline
\end{tabular}

Controls

1 R.P.

2 A.C.

3 P.W.

4 M.S.

5 E.C.

6 H.W

7 O.D.

8 M.M.

9 J.H.

10 T.M.

1 M.D.

$\begin{array}{ll}\mathbf{M} & 30 \\ \mathbf{M} & \mathbf{3 3} \\ \mathbf{F} & \mathbf{2 7} \\ \mathbf{F} & \mathbf{3 7} \\ \mathbf{F} & \mathbf{5} \\ \mathbf{F} & \mathbf{4 1} \\ \mathbf{F} & \mathbf{5 1} \\ \mathbf{F} & \mathbf{3 8} \\ \mathbf{M} & \mathbf{7 5} \\ \mathbf{F} & \mathbf{2 9}\end{array}$

12 M.R.

M 44

3 H.G.

14 H.T.

15 E.D.

16 B.B.

$\begin{array}{ll}\mathbf{M} & \mathbf{2 6} \\ \mathbf{M} & \mathbf{5 9} \\ \mathbf{F} & \mathbf{6 2} \\ \mathbf{M} & \mathbf{5 9}\end{array}$

\section{$5 \cdot 8$}

$7 \cdot 4$

$7 \cdot 9$

$8 \cdot 0$

$5 \cdot 1$

6.7

$5 \cdot 7$

$6 \cdot 4$

$8 \cdot 9$

$6 \cdot 4$

$8 \cdot 7$

$8 \cdot 5$

$7 \cdot 1$

$6 \cdot 5$

6.3

17 S.B.

M $\quad 56$

$7 \cdot 8$

Idiopathic Steatorrhoea

1 M.W. F 65

2 M.F.

3 M.W.

4 G.H.

5 C.F.

6 M.J.

7 J.J.

E.A.

9 G.W.

$\begin{array}{ll}\mathbf{F} & 65 \\ \mathbf{M} & \mathbf{4 8} \\ \mathbf{F} & \mathbf{5 9} \\ \mathbf{M} & \mathbf{6 7} \\ \mathbf{F} & \mathbf{5 5} \\ \mathbf{M} & \mathbf{5 8} \\ \mathbf{F} & \mathbf{7 5} \\ \mathbf{M} & \mathbf{6 1}\end{array}$

$$
5 \cdot 0
$$

$5 \cdot 7$

$1 \cdot 1$

$1 \cdot 3$

3.6

0.6

$2 \cdot 4$

0.9

$3 \cdot 2$

10 F.D.

11 G.M.

$\begin{array}{lll}M & 62 & 4 \cdot 0\end{array}$

F 35

$3 \cdot 4$

$2 \cdot 9$

$2 \cdot 6$

$2 \cdot 9$

1.4

0.8

15 M.C.

16 A.C.

Enteritis

Jejunitis

$\begin{array}{llllll}1 & \text { E.P. } & \text { M } & 50 & 4 \cdot 6 & 27 \cdot 0 \\ 2 & \text { G.W. } & \text { M } & 60 & 3 \cdot 1 & 13 \cdot 0 \\ 3 & \text { M.H. } & \text { M } & 38 & 3 \cdot 0 & 25 \cdot 3 \\ 4 & \text { I.L. } & \text { F } & 29 & 5 \cdot 2 & 3 \cdot 5\end{array}$

$\begin{array}{llllll}4 & \text { I.L. } & \text { F } & 29 & 5.2 & 3.5\end{array}$

Ileitis

1 D.G. F $53 \quad 6.5$

$\begin{array}{lllll}2 & \text { L.P. } & M & 25 & 6.8\end{array}$

3 G.T. $\quad$ F 38

$5 \cdot 9$

4 A.J. F 29

$\begin{array}{llll}5 & \text { P.D. } & \text { M } & 56 \\ 6 & \text { R.V. } & \text { F } & 42\end{array}$

$6 \cdot 9$

$3 \cdot 4$
$7 \cdot 6$

$\begin{array}{lllll}7 & \text { V.C. } & \text { F } & 26 & 6.4\end{array}$

Post-gastrectomy Steatorrhoea

1 L.H.

2 E.W.

3 G.M.

4 N.G.

\begin{tabular}{lrr}
$\mathbf{F}$ & 67 & $5 \cdot 7$ \\
$\mathbf{M}$ & 55 & $6 \cdot 2$ \\
$\mathbf{M}$ & 24 & $5 \cdot 7$ \\
$\mathbf{M}$ & 61 & $7 \cdot 3$ \\
\hline & 0 & $6 \cdot 4$
\end{tabular}

\section{-
-
-
-
-
-
3.2
3.5
3.7
4.6
2.3
4.0
-
2.7
-}

$-$

$24 \cdot 4$

$9 \cdot 3$

$25 \cdot 8$

$21 \cdot 5$

$11 \cdot 7$
$33 \cdot 2$

$17 \cdot 2$

20.7

13.0

$15 \cdot 5$

$15 \cdot 3$

$9 \cdot 8$
$12 \cdot 8$

$11 \cdot 6$

$19 \cdot 0$

$7 \cdot 4$

$27 \cdot 0$

$13 \cdot 0$

$25 \cdot 3$

$\cdot 5$

5 A.R.

6.4

\begin{tabular}{ll}
- & - \\
- & - \\
- & - \\
- & - \\
- & - \\
- & - \\
- & - \\
\hline Normal & Normal \\
Normal & Normal \\
? Mild steatorrhoea & Normal \\
pattern & Normal \\
Normal & Normal \\
Normal & - \\
Normal & - \\
\hline Deformed duodenal & - \\
cap, small duo- & \\
denal ulcer & \\
Normal & - \\
&
\end{tabular}

Deficiency pattern Deficiency pattern Deficiency pattern Deficiency pattern Deficiency pattern Deficiency pattern Deficiency pattern Deficiency pattern Deficiency pattern Dilatation and

fluid levels

Normal

Deficiency pattern

Deficiency pattern

Deficiency pattern

Normal

Deficiency pattern

Deficiency pattern

Subtotal villous atrophy Subtotal villous atrophy Complete villous atrophy Subtotal villous atrophy Partial villous atrophy Subtotal villous atrophy Subtotal villous atrophy Subtotal villous atrophy Subtotal villous atrophy

Partial villous atrophy Subtotal villous atrophy Subtotal villous atrophy Subtotal villous atrophy Subtotal villous atrophy

Subtotal villous atrophy

Subtotal villous atrophy

Strictures of duo- Laparotomy biopsy of denum and jejunum jejunum showed subtotal

Small intestinal

obstruction

Small intestinal Normal

obstruction

Crohn's disease of Normal jejunum

Crohn's disease of -

ileum

Terminal ileitis

Terminal ileitis

Normal

Normal-partial villous

Terminal ileitis atrophy

Normal Normal

Dilatation of ileal Normal

loops

Narrowing of -

terminal ileum

Normal

Normal

Normal

Delayed emptying of stomach
Staff

Staff

Stafi

Staff

Staff

Staff

Staff

Pernicious anaemia

Anaemia

Diarrhoea

Diarrhoea

Diarrhoea, anxiety state

Recurrent diarrhoea

Haematemesis

Cholelithiasis

Haematemesis

Abdominal pain due to musculoskeletal causes

Diagnosis confirmed at operation

Diagnosis confirmed at operation

Diagnosis confirmed at operation

Diagnosis confirmed at operation

No laparotomy

Diagnosis confirmed at operation

Diagnosis confirmed at operation

Diagnosis confirmed at operation Diagnosis confirmed at operation Diagnosis confirmed at operation

Diagnosis confirmed at operation

Partial gastrectomy

Total gastrectomy

Partial gastrectomy

Partial gastrectomy

Partial gastrectomy 
Steatorrhoea was confirmed in all cases. The barium meal and follow-through in all cases showed a normal jejunum. In three of the five patients subjected to peroral biopsy a normal mucosa was found. The average age in this group was 51.4 years.

RESULTS

The average urinary xylose excretion in the 17 control subjects was $6.94 \mathrm{~g}$. in five hours (Table II). For the 10 cases under the age of 50 the average was $7.20 \mathrm{~g}$. and for those over 50 it was $6.56 \mathrm{~g}$. Only one patient (aged 44) excreted less than $5 \mathrm{~g}$. in five hours. In the idiopathic steatorrhoea group (16 patients) the xylose excretion ranged from 0.6 to $5.7 \mathrm{~g}$., with an average of $2.61 \mathrm{~g}$. Only one patient excreted above $5 \mathrm{~g}$. of xylose. The average xylose excretion for the entire group with Crohn's disease (11 patients) was $5.40 \mathrm{~g}$. These results were then graded according to jejunal and ileal involvement. In the four patients

TABLE II

AVERAGE URINARY XYLOSE EXCRETION

\begin{tabular}{|c|c|c|c|c|}
\hline Group & $\begin{array}{l}\text { No. of } \\
\text { Patients }\end{array}$ & $\begin{array}{l}\text { Average Age } \\
\text { (yr.) }\end{array}$ & $\begin{array}{l}D(+) \text { Xylose Urinary } \\
\text { Mean }(\mathrm{g} .15 \text { hours })\end{array}$ & Range \\
\hline Controls & 17 & $44 \cdot 4$ & 6.94 & $\begin{array}{l}4 \cdot 7-8 \cdot 9 \\
\text { Standard deviation } 1 \cdot 18\end{array}$ \\
\hline $\begin{array}{l}\text { Under } 50 \\
\text { Over } 50\end{array}$ & $\begin{array}{r}10 \\
7\end{array}$ & $\begin{array}{l}33 \cdot 9 \\
59 \cdot 4\end{array}$ & $\begin{array}{l}7.20 \\
6.56\end{array}$ & $\begin{array}{l}4 \cdot 7-8 \cdot 9 \\
5 \cdot 1-7 \cdot 8\end{array}$ \\
\hline Idiopathic steatorrhoea & 16 & $54 \cdot 8$ & $2 \cdot 61$ & $\begin{array}{l}0.6-5 \cdot 7 \\
\text { Standard deviation } 1.49\end{array}$ \\
\hline $\begin{array}{l}\text { Enteritis } \\
\text { Jejunitis } \\
\text { Ileitis }\end{array}$ & $\begin{array}{r}11 \\
4 \\
7\end{array}$ & $\begin{array}{l}40 \cdot 5 \\
44 \cdot 3 \\
38 \cdot 4\end{array}$ & $\begin{array}{l}5.40 \\
3.98 \\
6 \cdot 21\end{array}$ & $\begin{array}{l}3 \cdot 0-7 \cdot 6 \\
3 \cdot 0-5 \cdot 2 \\
3 \cdot 4-7 \cdot 6\end{array}$ \\
\hline Post-gastrectomy steatorrhoea & 5 & $51 \cdot 4$ & $6 \cdot 26$ & $5 \cdot 7-7 \cdot 3$ \\
\hline $\begin{array}{l}\text { Repeat investigation on idiopathic } \\
\text { steatorrhoea after gluten-free diet }\end{array}$ & 9 & $53 \cdot 1$ & $4 \cdot 60$ & $1 \cdot 0-7 \cdot 2$ \\
\hline
\end{tabular}

TABLE III

URINARY XYLOSE AND FAECAL FAT EXCRETION AND BIOPSY RESULTS AFTER TREATMENT

\begin{tabular}{|c|c|c|c|c|c|c|}
\hline & ase No. & $\begin{array}{l}\text { Period of Study } \\
\text { in Months }\end{array}$ & Therapy & $\begin{array}{l}\text { Urinary Xylose } \\
\text { Excretion } \\
\text { (g./5 hours) }\end{array}$ & $\begin{array}{l}\text { Faecal Fat } \\
\text { Excretion } \\
\text { (g./24 hours) }\end{array}$ & $\begin{array}{l}\text { Result of Small } \\
\text { Intestinal Biopsy }\end{array}$ \\
\hline 1 & M.W. & $\begin{array}{l}\text { Initial } \\
1 \\
8\end{array}$ & 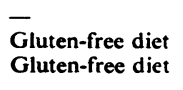 & $\begin{array}{l}5 \cdot 0 \\
6 \cdot 7 \\
7 \cdot 2\end{array}$ & $\begin{array}{r}24 \cdot 4 \\
7 \cdot 6 \\
4 \cdot 7\end{array}$ & $\begin{array}{l}\text { Subtotal villous atrophy } \\
\overline{\text { Partial villous atrophy }}\end{array}$ \\
\hline 2 & C.F. & $\begin{array}{l}\text { Initial } \\
1\end{array}$ & $\overline{\text { Gluten-free diet }}$ & $\begin{array}{l}3 \cdot 6 \\
6 \cdot 9\end{array}$ & $\begin{array}{r}11 \cdot 7 \\
3 \cdot 6\end{array}$ & $\begin{array}{l}\text { Partial villous atrophy } \\
\text { Partial villous atrophy }\end{array}$ \\
\hline 3 & J.J. & $\begin{array}{l}\text { Initial } \\
1 \\
5 \\
8\end{array}$ & $\begin{array}{l}\text { Gluten-free diet } \\
\text { Gluten-free diet } \\
\text { Gluten-free diet }\end{array}$ & $\begin{array}{l}2 \cdot 4 \\
1 \cdot 6 \\
3 \cdot 2 \\
1 \cdot 9\end{array}$ & $\begin{array}{r}17 \cdot 2 \\
\frac{-}{15 \cdot 5} \\
5 \cdot 8\end{array}$ & $\begin{array}{l}\text { Subtotal villous atrophy } \\
\text { Subtotal villous atrophy } \\
- \\
-\end{array}$ \\
\hline 4 & E.A. & $\begin{array}{l}\text { Initial } \\
1 \\
8\end{array}$ & $\begin{array}{l}\overline{\text { Gluten-free diet }} \\
\text { Gluten-free diet }\end{array}$ & $\begin{array}{l}0.9 \\
1 \cdot 1 \\
1.0\end{array}$ & $\begin{array}{l}20 \cdot 7 \\
19 \cdot 0 \\
22 \cdot 7\end{array}$ & $\begin{array}{l}\text { Subtotal villous atrophy } \\
\overline{\text { Subtotal villous atrophy }}\end{array}$ \\
\hline 5 & F.I). & $\begin{array}{l}\text { Initial } \\
6\end{array}$ & $\overline{\text { Gluten-free diet }}$ & $\begin{array}{l}4 \cdot 0 \\
4 \cdot 2\end{array}$ & $\begin{array}{r}15 \cdot 5 \\
7 \cdot 7\end{array}$ & $\begin{array}{l}\text { Partial villous atrophy } \\
-\end{array}$ \\
\hline 6 & G.M. & $\begin{array}{l}\text { Initial } \\
9\end{array}$ & $\overline{\text { Gluten-free diet }}$ & $\begin{array}{l}3 \cdot 4 \\
5 \cdot 3\end{array}$ & $\begin{array}{r}15 \cdot 3 \\
3 \cdot 1\end{array}$ & $\begin{array}{l}\text { Subtotal villous atrophy } \\
\text { Subtotal villous atrophy }\end{array}$ \\
\hline 7 & R.D. & $\begin{array}{l}\text { Initial } \\
10\end{array}$ & $\overline{\text { Gluten-free diet }}$ & $\begin{array}{l}2 \cdot 9 \\
4 \cdot 7\end{array}$ & $\begin{array}{l}9 \cdot 8 \\
8 \cdot 1\end{array}$ & $\begin{array}{l}\text { Subtotal villous atrophy } \\
-\end{array}$ \\
\hline 8 & W.S. & $\begin{array}{l}\text { Initial } \\
4\end{array}$ & $\overline{\text { Gluten-free diet }}$ & $\begin{array}{l}2 \cdot 9 \\
6 \cdot 6\end{array}$ & $\begin{array}{r}11.6 \\
1.9\end{array}$ & $\begin{array}{l}\text { Subtotal villous atrophy } \\
\text { Subtotal villous atrophy }\end{array}$ \\
\hline 9 & M.C. & $\begin{array}{l}\text { Initial } \\
6\end{array}$ & $\overline{\text { Gluten-free diet }}$ & $\begin{array}{l}1 \cdot 4 \\
3 \cdot 6\end{array}$ & $\begin{array}{r}19 \cdot 0 \\
7 \cdot 7\end{array}$ & $\begin{array}{l}\text { Subtotal villous atrophy } \\
\text { Subtotal villous atrophy }\end{array}$ \\
\hline
\end{tabular}


with jejunal disease the average xylose excretion was $3.98 \mathrm{~g}$. whereas in the seven patients with ileal disease it was $6.21 \mathrm{~g}$. In all five patients with postgastrectomy steatorrhoea the xylose excretion was normal and the average was $6.26 \mathrm{~g}$.

In nine of the 16 patients with idiopathic steatorrhoea repeat investigations were carried out from one to 10 months after they started on a gluten-free diet, and faecal fat estimations as well as peroral small intestinal biopsy were carried out at the same time wherever possible (Table III). Their average xylose excretion was $2.61 \mathrm{~g}$. before treatment and was raised to $4.60 \mathrm{~g}$. after the gluten-free diet. In four patients the repeat xylose estimations rose to normal limits. In five patients (J.J., F.D., E.A., R.D., and M.C.) the urinary xylose excretion remained below $5 \mathrm{~g}$. Three of these five patients (F.D., R.D., and M.C.) responded well clinically to the gluten-free diet but only two showed a definite though subnormal improvement in xylose excretion. Repeat faecal fat estimations in these three patients likewise showed improvement in the steatorrhoea although again normal values were not obtained. Only one of these three patients (M.C.) was subjected to repeat biopsy and no improvement was evident histologically. Of the two patients not responding to the gluten-free diet (J.J. and E.A.) one showed a reduction in stool fat to near normal level but the other showed no reduction. Repeat biopsies in both patients showed no improvement.

The four pationts with idiopathic steatorrhoea in whom normal xylose values were obtained after treatment showed a good clinical response to the gluten-free diet, and faecal fat estimations declined to within normal limits. All four patients were subjected to repeat biopsy. In one patient there was a definite histological improvement and the mucosal appearance was one of partial villous atrophy where previously a subtotal villous atrophy was present. The other three patients showed no histopathological change from the original biopsy.

\section{DISCUSSION}

The urinary xylose excretion values in the control group agree well with those of other authors (Brien et al., 1952; Fourman, 1948; Christiansen et al., 1959; Shamma'a and Ghazanfar, 1960). They are said to decline with advancing age (Fowler and Cooke, 1960; Finlay and Wightman, 1958). In our control subjects there was also a slight decrease noted in those over 50 but in no case was the level below $5 \mathrm{~g}$. Moreover, the average value in the older control group was still nearly two and a half times greater than in patients in the idiopathic steatorrhoea group whose average age was over 50.
Other authors (Christiansen et al., 1959; Roberts, Beck, Kallos, and Kahn, 1960) have shown that improvement in xylose absorption and excretion occurred in patients with idiopathic steatorrhoea on a gluten-free diet. Our nine patients in whom repeat tests were carried out showed a rise from an average of 2.61 to $4.60 \mathrm{~g}$. in the five-hour urinary xylose excretion. However, on close analysis it became evident that not all patients showed such improvement. We usually, but not invariably, found an increase in xylose excretion in patients in whom a good clinical response was obtained with a glutenfree diet. This usually paralleled an improvement in fat absorption but showed no correlation with biopsy appearances which, with the exception of one case, remained unchanged.

In the group of patients with regional enteritis intermediate values for xylose excretion between the normal and idiopathic steatorrhoea have been reported by some authors (Christiansen et al., 1959). Others (Fowler and Cooke, 1960) have found normal xylose excretion in this group. Our results seem to indicate a decrease in xylose excretion values with the jejunal type and a normal excretion with the ileal type of regional enteritis. Along with a decrease in xylose excretion can usually be demonstrated a malabsorption of fat and of folic acid in the jejunal type of disease (Shiner and Drury, 1962). In those with ileal involvement (seven patients) only one showed an excess of faecal fat in spite of a normal xylose excretion. Conversely, the only patient to show a subnormal xylose excretion had normal faecal fat values.

That steatorrhoea per se can occur independently of malabsorption of sugars can best be demonstrated in our group of five patients with steatorrhoea after gastrectomy, all of whom showed normal xylose excretion levels, and, incidentally, normal peroral mucosal biopsies. Our results in this group of patients correlate well with those of other authors (Fowler and Cooke, 1960).

Our thanks are due to the physicians who kindly referred their patients to us. It is with particular pleasure that we would like to thank Mrs. E. E. Cox for her assistance and supervision during the tests.

One of us (M.S.) has been in receipt of a grant from the Medical Research Council whose assistance is herewith gratefully acknowledged.

\section{REFERENCES}

Anderson, C. M., French, J. M., Sammons, H. G., Frazer, A. C., Gerrard, J. W., and Smellie, J. M. (1952). Coeliac disease: gastro-intestinal studies and the effect of dietary wheat flour. Lancet, 1, 836-842. 
Benson, J. A. Jr., Culver, P. J., Ragland, S., Jones, C. M., Drummey, G. D., and Bougas, E. (1957). The D-xylose absorption test in malabsorption syndromes. New Engl. J. Med., 256, 335-339.

Brien, F. S., Turner, D. A.. Watson, E. M., and Geddes, J. H. (1952). A study of carbohydrate and fat absorption from the normal and diseased intestine of man. I. The absorption and excretion of D-xylose. Gastroenterology, 20, 287-293.

Butterworth, C. E. Jr., Perez-Santiago, E., Martinez de Jesus, J., and Santini, R. (1959). Studies on the oral and parenteral administration of $\mathrm{D}(+)$ xylose. New Engl. J. Med., 261, 157-164.

Christiansen, P. A., Kirsner, J. B., and Ablaza, J. (1959). D-xylose and its use in the diagnosis of malabsorptive states. Amer. J. Med., 27. 443-453.

Finlay, J. M., and Wightman, K. J. R. (1958). The xylose tolerance test as a measure of the intestinal absorption of carbohydrate in sprue Ann. intern. Med., 49, 1332-1347.

Fourman, L. P. R. (1948). The absorption of xylose in steatorrhoea. Clin. Sci., 6, 289-294.
Fowler, D., and Cooke, W. T. (1960). Diagnostic significance of D-xylose excretion test. Gut, 1, 67-70.

Roe, J. H., and Rice, E. W. (1948). A photometric method for the determination of free pentoses in animal tissues. J. biol. Chem., 173, 507-512.

Roberts, J. G., Beck, I. T., Kallos, J., and Kahn, D. S. (1960). D(+) xylose blood-level time-curve as an index of intestinal absorption. Canad. med. Ass. J., 83, 112-117.

Shamma'a, M. H., and Ghazanfar, S. A. S. (1960). D-xylose test in enteric fever, cirrhosis, and malabsorptive states. Brit. med. J., 2, 836-838.

Shiner, M. (1956). Duodenal biopsy. Lancet, 1, 17-19.

- and Drury, R. A. B. (1962). Abnormalities of the small intestinal mucosa in Crohn's disease (regional enteritis). Amer. J. dig. Dis., in press.

Turner, D. A. (1950). Absorption from the intestine. Thesis. University of Western Ontario, London, Ontario. 